\title{
Monitoring System of Humidity Environmental on Chilli Red Green House Aeroponic System
}

\author{
*Alimuddin and Dwi Rahmat Aryanto \\ Department of Electrical Engineering \\ University of Sultan Ageng Tirtayasa \\ Jl Jendral Sudirman Km03, Cilegon, Indonesia \\ *alimuddin@untirta.ac.id \\ Rida Oktorida Khastini and Nurmayulis \\ Department of Biology Education and Department of \\ Agroecotechnology \\ University of Sultan Ageng Tirtayasa \\ Jl Raya Jakarta Km04, Pakupatan Serang, Indonesia
}

rida.khastini@untirta.ac.id

\author{
Dewa Made Subrata \\ Department of Mechanical and Biosystem \\ Bogor Agriculture University \\ Darmaga Bogor, Indonesia \\ dewamadesubrata@yahoo.com
}

\author{
Ria Arafiyah \\ Department of Computer Science \\ Jakarta State University \\ Jl Pemuda No 10 Ramawangun, Indonesia \\ riaarafiah@unj.ac.id
}

\author{
Irma Saraswati \\ Department of Electrical Engineering \\ Faculty of Engineering \\ Universitas Sultan Ageng Tirtayasa, Indonesia
}

\begin{abstract}
The research aims at monitoring the humidity of chilli plants on aeroponic growing media in greenhouses. The aeroponic system is used because of limited land for planting chili, while the Greenhouse is designed to manipulate the climate needed for chili plants to be able to grow optimally to produce chili with good quality and quantity. Moisture measurements are carried out using the DHT11 sensor connected to Arduino Mega 2560. The humidity value is monitored in the morning, afternoon and evening. The moisture value read by the DHT11 sensor is displayed on the 16x2 LDC (Liquid Crystal Display) found on the aeroponic table to make it easier to observe the moisture values needed by chili plants. The monitoring results are 3 morning conditions between $83 \%-95 \%$, Daytime $63 \%-79 \%$, Afternoon $\mathbf{7 8 \%}-\mathbf{8 4} \%$ This is the material of knowledge before exercising humidity control according to the aeroponic setpoint in the greenhouse.
\end{abstract} chili.

Keywords: Moisture monitoring, aeroponics, Greenhouse, red

\section{INTRODUCTION}

One of the horticultural products that is superior in the agricultural sector in Indonesia is vegetable crops. Vegetables are one of the horticultural products that are in great demand by the community because they have nutritional benefits that are beneficial to health. Vegetables can be consumed raw or processed first according to the needs to be used. One of the vegetable commodities that is needed by almost all people from various walks of life is chili, so it is not surprising that the volume of circulation in the market is on a large scale. Red chili (Capsicum annum L.) is one of the types of horticulture plants that are commercially cultivated, this is because in addition chili has good nutrient content chili also has high economic value and is widely used for household consumption or food industry needs. Red chili contains nutrients needed by humans such as vitamin A, vitamin C, carotene, iron, potassium, calcium, and phosphorus and also contains alkaloids such as kapaicin, flavenoid, and essential oils and also red chili has benefits for cooking spices or mixed ingredients in various food processing industries [1]. Efforts made to increase the productivity of chili plants can be done in various ways. One way to do this is to improve cultivation technology, namely with large use, but not infrequently, red chilli farmers encounter failures and losses. Demand for chili not throughout the year can be fulfilled. The lack of supply causes the price of chili to soar so that it often causes inflation. The problem of chili is actually not only when prices soar due to reduced supply, but also at the time of the drop in the price of chillies due to the abundant supply so that farmers experience substantial losses. The smartest factor from the sustainability of chili plants is the planting environment. One of them is the air humidity factor.

The humidity that is suitable for chili plants ranges from $60-80 \%$, especially when flower and fruit formation. Humidity that exceeds $80 \%$ spurs the growth of fungi that have the potential to attack and damage plants. Conversely, a climate that is less than $60 \%$ makes chili dry and disrupts its generative growth, especially when flower formation, pollination, and fruit formation [2]. The use of greenhouses is useful for regulating and monitoring moisture so that chili plants can grow optimally. Greenhouse is a construction building that functions to avoid and manipulate environmental conditions in order to create the desired environmental conditions in plant maintenance. Greenhouse that is able to create a climate that can make plants capable of producing without knowing this season is also able to avoid pests and diseases that are not tested. In addition, with the Greenhouse the spread of pests and diseases being tested can be prevented. Modern Greenhouse technology has weather engineering capabilities [3]. 
State of the art research is The Aeroponics is derived from the word aero which means air and ponus which means power. The aeroponics are empowering the air. Aeroponic is one type of hydroponics because water containing nutrient solution is sprayed in the form of mist to the roots of plants. The sensors used are environmental temperature, humidity sensors and environmental temperature sensors. [4,5] and application of PLC (Programmable Logic Controller) for cultivation of chrysanthemum hydroponics system. This study uses temperature sensors, $\mathrm{RH}$, and nutrients [6]. The research of nozel applications in two potato varieties for aeroponic seed production [7]. The research System of automatic temperature and humidity parameter control of aeroponic system fertilization in caisim [8,9]. The aim is to monitor the environmental humidity of the aeroponic system with chili planting media on the Greenhouse.

\section{METHODS}

The moisture monitoring system in red chili plants using the aeroponic system in the Greenhouse is a monitoring open system. The sensor will read the humidity on the aeroponic system then it will be sent to the microcontroller and then forwarded to be displayed via LCD 16x2, as seen in Figure 1

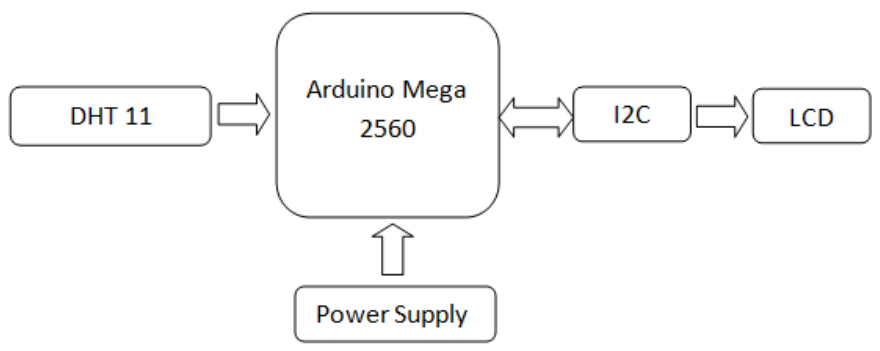

Figure 1. Moisture Monitoring System Block Diagram

ATMega 2560 microcontroller has several features specifications that make it an effective controlling solution for various purposes. These features include: Operation of $5 \mathrm{Vc}$, Input voltage of 6 - $20 \mathrm{~V}$ but recommended for ATMega 2560 for $7-12 \mathrm{~V}$., $156 \mathrm{~Kb}$ Flash memory which is $8 \mathrm{~Kb}$ used by bootloader, Current DC pin I / O for $40 \mathrm{~mA}$ while the DC current for $3.3 \mathrm{~V}$ pins is $50 \mathrm{~mA}, 4$ Kbyte EEPROM, 8 Kbyte SRAM, and has 2 UART ports for serial communication. 16 pin analog input pin and 54 pin digital I / O pin where 14 pins are output from PWM.

Greenhouse is built using mild steel material that is able to hold plant media from factors that can damage plants. Greenhouses measuring 3.6 meters long, 3 meters wide and 3 meters high have roofs and walls with fiber material that serves to protect the aeroponic tables inside.

The greenhouse that has been made, inside it is designed an aeroponic system by using a table whose environment is controlled automatically. The use of greenhouses so that plants are protected from extreme weather, either hot air or excessive cold air, strong winds that can knock down plants and damage leaves. Protect plants from air and dust pollution. As a protector of plants from various animals, both large and small animals so they cannot enter and damage crops and improve the quality and quantity of crops.

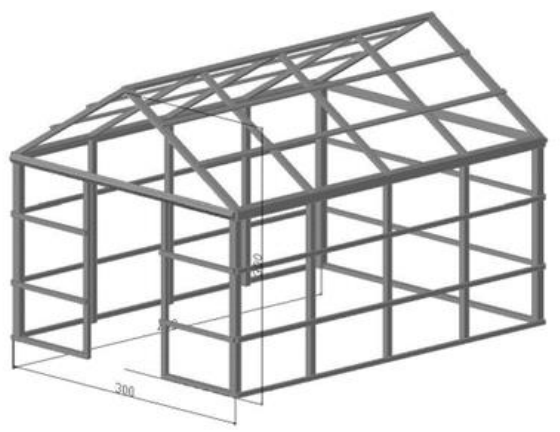

Figure 2. Greenhouse

Aeroponic table made of mild steel with a length of $2 \mathrm{~m}$ and a width of $1 \mathrm{~m}$ with a height of $0.9 \mathrm{~m}$. The table serves to place plants that have been placed previously on the netpot. On aeroponic tables, there are styrofoam which are given a netpot with a distance of $15 \mathrm{~cm}$ per netpot. As seen in Figure 4, the bottom of the table is installed in a hose and a mist sprayer which is inserted into the hose and then mounted hanging using a wire. Hose installation and mist sprayer function for watering from water reservoirs that have been filled with a mixture of Water and $\mathrm{AB}$ mix.

At table Figure 3 will be used as a place for research on aeroponic systems on red chili plants measuring only $1 \mathrm{~m}$ long and 1 meter wide or can be said to be half the size of an aeroponic table. At the table, a DHT11 sensor and a 16x2 LCD are placed which function as moisture monitoring.

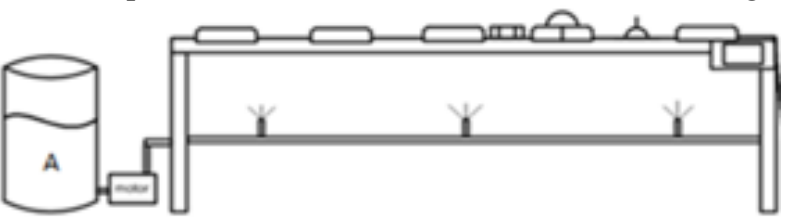

Figure 3 Aeroponic Table

\section{RESULT AND DISCUSSION}

\section{A. DHT11 Sensor Testing}

Testing the DHT 11 sensor used to measure the humidity value of the plant is done to determine the value of accuracy on the sensor.

Table 1. DHT 11 Measurement With HTC-1 Hygrometer

\begin{tabular}{|c|c|c|c|c|}
\hline Number & $\begin{array}{c}\text { Humudity } \\
(\% \mathrm{RH})\end{array}$ & $\begin{array}{c}\text { DHT 11 } \\
(\% \mathrm{RH})\end{array}$ & $\begin{array}{c}\text { Hygrometer } \\
\text { HTC-1 }(\% \mathrm{RH})\end{array}$ & $\begin{array}{c}\text { Error } \\
(\%)\end{array}$ \\
\hline 1 & 59 & 59 & 61 & 0,033 \\
\hline 2 & 64 & 64 & 65 & 0,015 \\
\hline 3 & 69 & 69 & 71 & 0,028 \\
\hline 4 & 71 & 71 & 72 & 0,014 \\
\hline 5 & 75 & 75 & 76 & 0,013 \\
\hline
\end{tabular}


The measurement results of the comparison between the DHT11 humidity sensor and HTC-1 digital hygrometer using the percentage error formula The result is quite good because the output value of the DHT11 humidity sensor is stable and almost close to the humidity value read by the HTC-1 hygrometer and still within the sensor error tolerance limit of 4\%. Moisture testing by comparing DHT11 sensors with digital thermometers.

\section{B. Monitoring Testing}

In microcontroller testing, monitoring humidity measurements on aeroponic systems is carried out. Tests are carried out in the morning from 10:00 to $11: 00$, during the day at 12:00 to $13: 00$ and in the afternoon at 4:00 p.m. to $17: 00$ for three weeks. This is done to make it easier to know the humidity conditions when growing red chili in a Greenhouse on an aeroponic system. The following are the results of monitoring tests:

1) The first Week Humidity Monitoring

Testing humidity monitoring in the first week is done in the morning is blue, in the day is green and in the afternoon is red for one week, then the graph in Figure 4 is obtained.

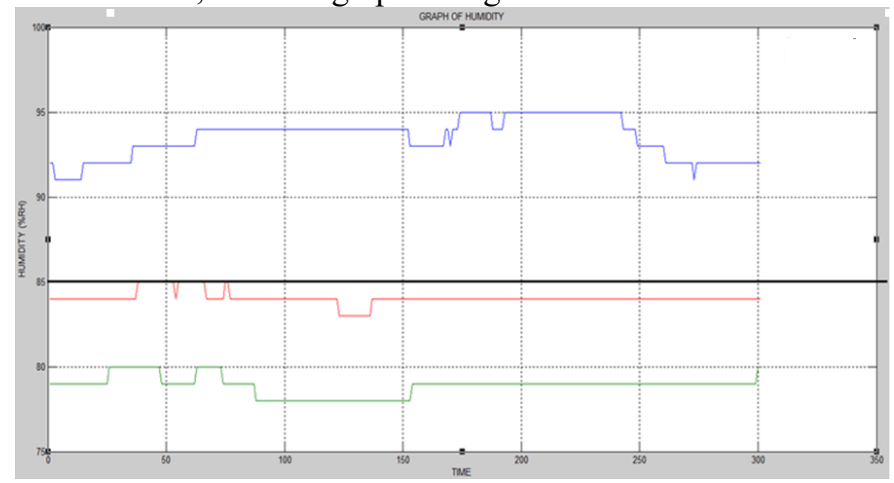

Figure 4. The first Week Humidity Monitoring

In the first week, Figure 4 shows the results of the DHT11 sensor readings of humidity values at different times. Humidity in the morning reaches $95 \% \mathrm{RH}$ (Relative Humidity), then during the daytime the average humidity is in the condition of $79 \%$ RH (Relative Humidity), and in the afternoon the average humidity conditions in the aeroponic environment are $84 \% \mathrm{RH}$ (Relative Humidity). The morning humidity in the aeroponic environment that is read by the DHT11 sensor is fairly humid because it is at a value of $95 \%$. This happens because in the morning the air in the aeroponic environment is still cool.

2) The second Week Humidity Monitoring

During the second week of humidity monitoring was carried out for one week during the morning from 10:00 to 11:00, during the day the data collection was carried out at 12:00 to 13:00 and in the afternoon the data collection was carried out at $16: 00$ to $17: 00$. This is done to find out the humidity in the second week to make it easier to grow crops. Figure 5 is the result of monitoring in the second week.

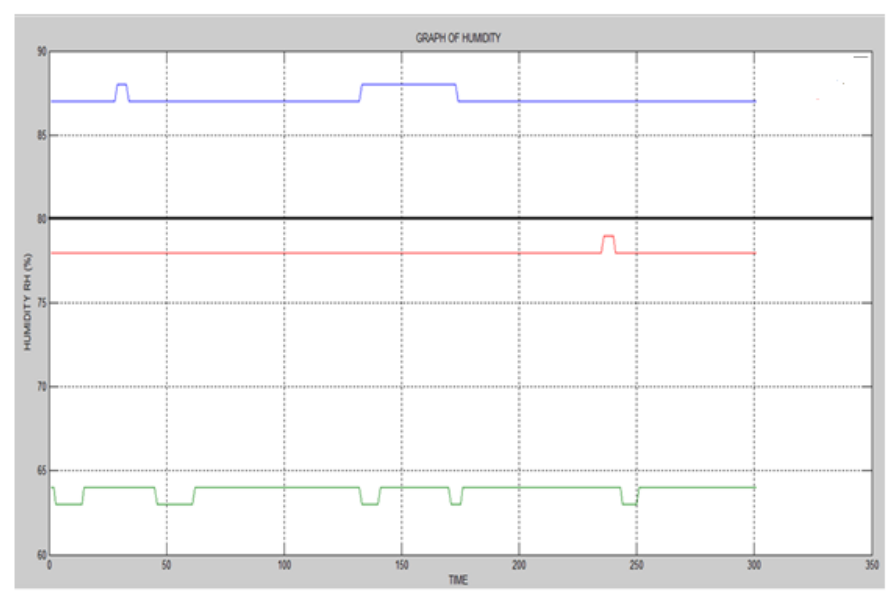

Figure 5. The second Week Humidity Monitoring

The results of humidity testing in the second week showed that the humidity in the morning was $87 \%$ RH (Relative Humidity), during the day the humidity read by the DHT11 sensor was 64\% RH (Relative Humidity), and in the afternoon 78\% RH (Relative Humidity). During the day and evening the humidity conditions in the aeroponic environment are in normal conditions. This condition is needed by chili in order to grow optimally.

3) The third Week Humidity Monitoring

Humudity testing in the third week is carried out for one week with the time of morning, day and afternoon. The following results of humudity testing in the third week can be seen in Figure 6.

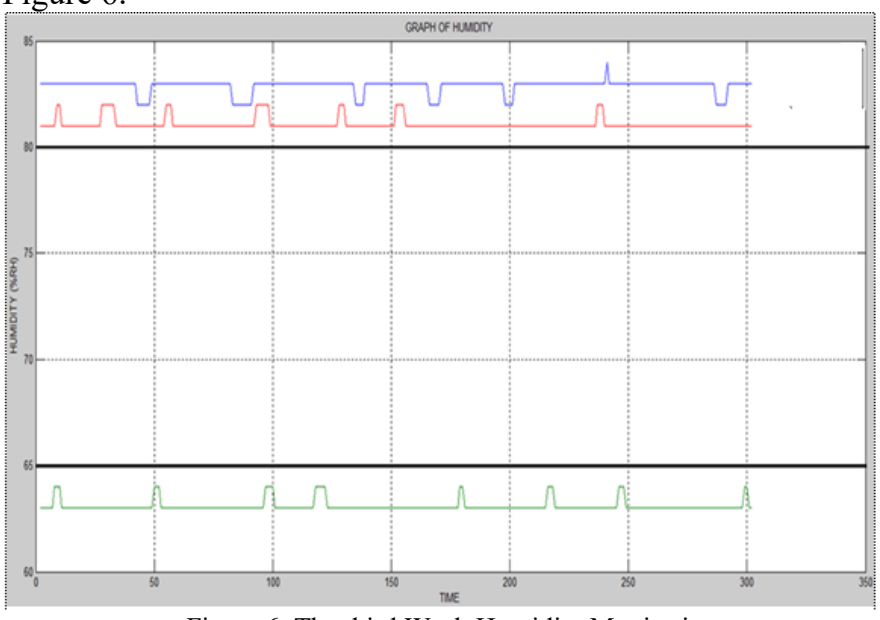

Figure 6. The third Week Humidity Monitoring

The results of monitoring chili plants on the aeroponic system in the third week can be seen in Figure 6. In the morning the average humidity value was at $83 \%$. During the day the average humidity value is $63 \%$ and $81 \%$ in the afternoon. Monitoring in the third week of humidity is outside the set point that can interfere with the planting of the chili plants 


\section{CONCLUSION}

Based on the results that have been done on the chili plant monitoring research, there are some conclusions including: the First, In the first week the humidity read by the DHT 11 sensor is at $79 \%$ to $95 \% \mathrm{RH}$ (Relative Humidity) where the humidity in the morning passes the moisture setpoint on the chili plants. The second week of humidity reads at $69 \%$ to $88 \%$ and in the third week at $63 \%$ to $83 \%$. the Second, By using an aeroponic system, farmers are able to plant chili on a narrow area. By using Greenhouse farmers can plant chili plants without knowing the season. the third, Factors that influence changes in the value of moisture at the research site are the environment around Greenhouse due to the climate at the research site.

\section{ACKNOWLEDGMENT}

Researchers thank the DRPM Ministry Higher Education and research technology given Grant Nation Strategy Institute 2018 and all UNTIRTA Leaders assist in conducting research including the use of laboratory Electrical Engineering Department and Research Place CoE Building Petrochemicals Faculty of Engineering Cilegon University of Sultan Ageng Tirtayasa and Laboratory Control and Instrumention Faculty of Agricultural Engineering Bogor Agriculture University.

\section{REFERENCES}

[1] N. Prasetyo, Muh. Kusberyunadi. "Response of Several Red Chilli (Capsicum Annuum L.) Varieties in Different Types of Cage Fertilizers", University of PGRI Yogyakarta.

[2] S. Syafrizal, N. B. William and N. A. Gendis, "Monitoring System for Temperature and Humidity of Chili Plants in LABVIEW-Based Greenhouses", Negri Polytechnic Jakarta, 2016.

[3] Abbas, Hamada. "Designing a Smart Greenhouse as a Place for Cultivating Plants Using Solar Cells as a Source of Electricity". Majoring in mechanical engineering. Banjarmasin. 2015

[4] Widodo, Muhammad. "Build an Automatic Aeroponic System for Cultivating Multiple Vegetables". UNIKOM Computer System. Bandung. 2015

[5] F. Akhmad, "Utilization of air temperature and air humidity in the regression equation to simulate the prediction of total monthly rainfall in Pinangang", Depati Amir Pangkalpinang Meteorological Station. 2013

[6] Suhardiyanto, H., Sukoco, H., Guritman, S., Prabowo, Y. dan Saptasari, H.K. (2012). application of PLC (Programmable Logic Controller) for cultivation of chrysanthemum hydroponics system. Department of Agricultural Engineering, Faculty of Agricultural Technology Bogor Agricultural University, Bogor

[7] Sumarni, 2014, Nozel Applications In Two Potato Varieties For Aeroponic Seed Production, Journal Biofisika, Vol.10, No.1. March 2014, 1-7

[8] Alimuddin, Ria Arafiyah, Kartina, Bagus Kukuh Udiarto, Suparlan, Yanto Surdiyanto, Raden Vergiansyah, 2015 Design of Auotmation Control System Parameter Humidity Fertigation Aeroponics System in Caisim, Proceeding Internasional Conference an Integrated View to International Development, Yogyakarta, 26-27 December 2015

[9] Alimuddin, Ria Arafiyah Kartina, Bagus Kukuh Udiarto, Suparlan, Yanto Surdiyanto, Raden Vergiansyah, 2015 Design of Automation Control Fetigation Parameters of Temperature of Aeroponic Systems in Caisim, Proceedings of the National Seminar on Control Instrumentation and Automation (SNIKO) 2015, ITB Bandung 10-11 Desember 2015. 